\title{
Optimizing the value of activity based costing system: The role of successful implementation
}

\author{
Ahmed Abdullah Saad Al-Dhubaibi ${ }^{a^{*}}$
}

${ }^{a}$ Department of Accounting, College of Business Administration, Prince Sattam Bin Abdulaziz University, Al-Kharj, Saudi Arabia

C H R O N I C L E

\begin{tabular}{l} 
Article history: \\
Received: July 7, 2020 \\
Received in revised format: \\
August 102020 \\
Accepted: August 16, 2020 \\
Available online: \\
August 16, 2020 \\
\hline Keywords: \\
Activity-based costing \\
Implementation success \\
Extent of use, benefits \\
User satisfaction
\end{tabular}

A B S T R A C T

\begin{abstract}
Activity-based costing system (ABC) adopters reported different uses of the system, inconsistent amounts of benefits gained, and consequently varying levels of satisfaction with the system. This study aims to investigate the variation in the extent of use, the magnitude of benefits, and user satisfaction with the ABC. A structured questionnaire was sent to the manufacturing companies operating in Riyadh Province, Saudi Arabia. 75 responses from ABC implementers were received. The results of this study show that the degree of $\mathrm{ABC}$ implementation success positively influences the extent of its use, the magnitude of benefits that have been obtained, and the overall user satisfaction with the system. These findings imply that irrespective of the characteristics of the company or the features of the system, the way the companies implement $\mathrm{ABC}$ might determine how much benefits can be gained and to what extent the system could be used.
\end{abstract}

(C) 2021 by the authors; licensee Growing Science, Canada

\section{Introduction}

Activity-Based Costing (ABC) was developed in the late 1980s to overcome the deficiencies of the traditional costing systems (Brown et al., 1999) and to keep pace with the rapid technological advancements and automated manufacturing processes. As business competition increased substantially and the structure of manufacturing cost changed significantly, with an increased portion of the indirect costs, managers made the decisions to depend on the ABC in allocating costs to activities and then to products and services (Hilton, 2008). In addition to cost determination and cost control, ABC has been used for performance evaluation (Maiga \& Jacobs, 2008), products, services, and customers' profitability analysis (Nolan, 2004), allocating resources (Argyris \& Kaplan, 1994), gaining competitive advantages (Cohen et al., 2005), and for continuous improvements (Cagwin \& Bouwman, 2002). Despite the great interest in Activity-Based Costing that was evident in the large volume of the professional and academic publications besides the reported perceived advantages of ABC by managers and management accountants, there was evidence over the past two decades for the low rates of ABC adoption in both developed and developing countries (Chenhall, 2004; Cohen et al., 2005; Gosselin, 1997; Innes \& Mitchell, 1995; Kennett et al., 2007; Souissi, 2002). For instance, a recent study on ABC adoption by Irish firms revealed that only 18.7 percent of the surveyed firms have adopted ABC (Quinn, Elafi, \& Mulgrew, 2017). Studies on ABC adoption have shown different views and attitudes of firms towards the usefulness, applicability, relevance, efficiency, fitness, and cost-benefit analysis of the ABC system. Companies that have adopted the $\mathrm{ABC}$ system reported a significant degree of success and expressed the relevance and usefulness of the system by its multiple uses in various areas such as cost reduction, performance measurement, pricing, performance improvements, customer profitability analysis, budgeting, cost modeling, and other applications (Innes, Metchell, \& Sinclair, 2000). Adopters of $\mathrm{ABC}$ further emphasized that $\mathrm{ABC}$ has been successful and beneficial in many applications of management and accounting such as cost accounting, cost management, performance measurement, decision making, and general management purposes (Cohen et al., 2005). While the users of ABC argue that its benefits outweigh its costs, non-users, however, have different

\footnotetext{
* Corresponding author.

E-mail address: a.aldhubaibi@psau.edu.sa (A. A. S. Al-Dhubaibi) 
views. They argue that $\mathrm{ABC}$ is very complicated in its administrative and technical aspects and needs new systems and resources for collecting and processing data. They claim that these factors will make the cost of ABC implementation exceed its benefits. Others (non-users) justify non-adopting ABC for other reasons. They explain that ABC is not a suitable costing system for their businesses or at least its benefits to their businesses might be low due to the characteristics of their businesses such as the low overhead cost, the small number of product lines, and less complexity (Innes et al., 2000). Similarly, while the users of $\mathrm{ABC}$ reported no considerable difficulties in the implementation of the system, non-users of the system expect serious difficulties and problems when implementing ABC such as complexity, high cost, and lack of time and resources (Cohen et al., 2005; Sorros, Karagiorgos, \& Mpelesis, 2017). Recently, Pietrzak et al. (2020) emphasized that ABC adopters assess the difficulties of its implementation to be smaller than other groups of companies. Researchers have attributed these differences in the companies' views to the different levels of management satisfaction with the previously used cost accounting systems. In contrast to non-users; adopters and supporters of ABC believe that traditional costing system is not enough for their decision-making needs.

If $\mathrm{ABC}$ creates the wide advantages reported by companies which implemented the system (McGowan \& Klammer, 1997) and users of the system acknowledge that the financial benefits outweighed its cost (Innes et al., 2000), why is there a low adoption rate around the globe? And why some companies have gained valuable benefits from implementing the ABC system while others have totally failed to continue using it (Duh et al., 2009). The level of ABC implementation success has been different from company to another. Research on $\mathrm{ABC}$ success reported a variety of success/failure and satisfaction levels. The varying levels of success and satisfaction with the system have been attributed to a variety of technical, organizational, behavioral, and administrative factors (Agbejule, 2006; Chong \& Cable, 2002; Foster \& Swenson, 1997; Gosselin, 1997; Innes et al., 2000; Jarrar, Smith, \& Dolley, 2007; Krumwiede, 1998; Major \& Hopper, 2005; McGowan \& Klammer, 1997; Shields, 1995). Despite the substantial number of studies on ABC success, these studies attempted to explore the factors that are of critical importance for $\mathrm{ABC}$ implementation success or, on the other hand, those factors that may hinder the success of $\mathrm{ABC}$ implementation. Nevertheless, there is a lack of research on how a given level of implementation success could impact the amount and quality of the system outcomes. This paper aims to contribute to this research area by investigating the effect of the successful implementation of $\mathrm{ABC}$ on the level of satisfaction with the system, extent of use, and the range of benefits gained from the system.

\section{Literature Review and Hypotheses Development}

The main purpose of $\mathrm{ABC}$ is to aid management in decision-making. Therefore, companies should make a comparison between the cost they will have to incur for designing, using, and maintaining the ABC system and the expected benefits from $\mathrm{ABC}$ implementation. Companies should implement $\mathrm{ABC}$ if they expect that the benefits from $\mathrm{ABC}$ implementation outweigh the costs (Kennett et al., 2007). According to McGowan and Klammer (1997), the findings of a large number of research case studies reported that organizations gain various benefits from ABC implementation. Swenson (1995) in his study about the benefits of $\mathrm{ABC}$ to the manufacturing companies stated that the respondents of the questionnaire reported substantial improvements in one or more aspects of their cost management system. Generally, ABC users acknowledge important improvements in product costing, cost control, and performance measurement. Other studies that have been undertaken in developing countries such as Greece provided more evidence of $\mathrm{ABC}$ benefits that were gained by ABC adopters in multidimensional aspects of management's needs (Cohen et al., 2005). Cooper and Kaplan (1988) emphasized the ABC role in providing accurate information about the production, helping managers in decision making, and enhancing continuous operating improvements. Cohen et al. (2005) argued that ABC implementation provides plenty of benefits in the areas of cost accounting, cost management, performance measurement, decision-making, and general management. Cagwin and Bouwman (2002) have linked the benefits of $\mathrm{ABC}$ implementation to a number of factors that are considered as enabling conditions for firms in order to obtain more benefits from ABC. They have suggested factors such as sophisticated information technology, complex firm process, highly competitive environment, and low unused capacity as critical enabling conditions.

Innes and Mitchell (1995) highlighted the differences between traditional costing and ABC. They explained that traditional costing records cost by type of input with concentrations on cost elements while $\mathrm{ABC}$ emphasizes the way that costs are consumed. In this way, $\mathrm{ABC}$ supports the analysis for cost reduction. Case studies research has provided evidence on the role of $\mathrm{ABC}$ in cost reduction and cost control. Chong and Cable (2002) conducted a study on the implementation of $\mathrm{ABC}$ in an Australian Oil and Gas Company. The objectives of ABC implementation as revealed by the study were more effective cost management, more accurate costing information, and better cost control. The most important finding of this study is that the Oil and Gas Company has achieved these objectives. Another case study research has been carried out by Duh et al. (2009) on the implementation of $\mathrm{ABC}$ in a Taiwanese Textile Company revealed that the company has gained better insight into manufacturing expenses and obtained more accurate product cost information. Otley (2008) argued that most consultants of management accounting believe that providing more accurate product cost information is the main benefit of $\mathrm{ABC}$ implementation. He further stated that the innovation of cost driver concept instead of cost allocation rate enhances the process of cost management. In contrast to Otley's arguments, Japanese firms were interested in ABC because they perceived it as an assistant tool in their efforts for cost reduction. The purpose of ABC in Japan was not merely more accurate product costing (Souissi, 2002). Evidence on cost savings by ABC has been reported by Narayanan and Sarkar (2002) who conducted a study about the impact of $\mathrm{ABC}$ on managerial decisions at Insteel Industries Company in the USA. They stated that because of ABC analysis, a number of process improvements have been achieved and resulted in significant cost savings. ABC implementation 
involves large costs for designing and maintaining the system. This is due to the resources that should be devoted to the $\mathrm{ABC}$ software in addition to the management and employees' time commitment. Managers need to know whether ABC implementation will produce financial benefits that outweigh its associated costs (Cooper \& Kaplan, 1992). Before taking the significant decision to adopt $\mathrm{ABC}$, managers should verify the linkage between ABC and firm performance (Maiga \& Jacobs, 2008). Empirical studies about the linkage between $\mathrm{ABC}$ and firm performance have found a positive and significant association. Using a mail survey, Kennedy and Graves (2001) conducted a study on a sample of 47 UK firms that have adopted ABC. They compared ABC user firms with non-user firms from the same industry considering the same market capitalization between $\mathrm{ABC}$ users and their matched non-users. Then they computed buy-and-hold returns for both types of companies for three consecutive years. With controlling for other variables, the study findings revealed that ABC adopters have achieved three-year returns of 61 percent while non-adopters' counterparts gained only 34 percent. This study has introduced empirical evidence that $\mathrm{ABC}$ improves firm performance financially and by market measures. The researchers suggested that improved firm performance was due to better asset utilization and cost control.

Cagwin and Bouwman (2002) argued that firms obtain positive synergy from implementing management accounting initiatives such as ABC, just in time (JIT), and total quality management (TQM) simultaneously. They further argued that there is no evidence of achieving firm performance effectiveness from implementing ABC solely. Another finding of their study is that certain conditions can enhance the benefits of $\mathrm{ABC}$ implementation. They reported a positive association between $\mathrm{ABC}$ and improvement in return on investment (ROI) in firms with complex production and relatively high cost. This study provides a signal for ABC supporters to identify the appropriate circumstances that maximize ABC benefits. Stončiuviené, Ūsaitè-Duonielienè, \& Zinkevičienè, (2020) reported increased economic efficiency through the integration of ABC and lean accounting. Despite the wide range of benefits that have been reported by ABC adopters, researchers have identified four categories of companies with regards to their attitudes and reaction to the ABC system as an important innovation in the fields of costing, managerial accounting, and performance management. According to the previous studies that have surveyed the adoption and implementation of $\mathrm{ABC}$, some companies' managers claim that the cost of $\mathrm{ABC}$ as a cost system outweigh its advantages (Cohen et al., 2005; Faria, Ferreira, \& Trigueiros, 2018). This category of companies rejected the system and has no plan to attempt using it in the future. In the survey conducted by Innes and Mitchell (1995), 36\% of the respondents who rejected $\mathrm{ABC}$ attributed reasons for rejecting $\mathrm{ABC}$ to the large number of resources required for initiating, designing, and operating the system. Another group of companies has not yet adopted the system, but they believe that it is worthy to be adopted (Maelah \& Ibrahim, 2006). This group of companies perceives that the usefulness of ABC outweighs its cost and they have a plan to adopt and implement the system in the future. The third group of companies are the companies that had adopted the system and have abandoned it later (Stratton, Desroches, Lawson, \& Hatch, 2009). These companies declared important challenges in implementing the system such as the high cost of constantly updating cost drivers and collecting ABC data (Liu and Pan, 2007), Complexity of the system (Chong and Cable, 2002) and Organizational resistance, (Narayanan and Sarkar, 2002). This category of companies discontinued using the system and has been classified by researchers as the unsuccessful implementers. The fourth group of companies is the adopters of the system who have continued to implement it. This group of companies "successful implementers" has argued that ABC system provides their managements with the accurate, relevant, and essential information for costing, performance measurement, and decision making in the financial, operational, and administrative activities of their businesses (Foster \& Swenson, 1997; Gosselin, 1997; Innes et al., 2000; Jarrar, Smith, \& Dolley, 2007; Krumwiede, 1998). However, a considerable number of studies on ABC implementation revealed various levels of satisfaction with the system and inconsistent outcomes from its implementation. In the meanwhile, some implementers declared that they are moderately successful in the system implementation while others assured that they are very successful (Agbejule, 2006; Chong \& Cable, 2002; Major \& Hopper, 2005). Researchers have investigated the factors that facilitate the successful implementation of $\mathrm{ABC}$ and conditions that may hinder such success. However, there is a lack of research that explains the variation of users' satisfaction with the system and outcomes of its implementation. This study attempts to answer the question of why companies report inconsistent outcomes and different levels of users' satisfaction. According to the contingency theory, there is no single way of implementing any performance management system that is suitable for all companies. Rather, performance management and control systems should be tied with the specific organizational structure, nature of business activities, size, and other organizational and environmental factors. In addition, these systems must meet the specific needs of each organization in order to yield the desired outcomes (Covaleski, Dirsmith, \& Samuel, 1996). Hence, $\mathrm{ABC}$ system implementation success is conditional on its fit to the structure and type of the organization. ABC success is found to be contingent not only on organizational factors, but also on environmental factors such as environmental uncertainty and market orientation (Albalaki, Abdullah, \& Kamardin, 2019). Based on the contingency theory proposition and the discussed literature of the previous studies that have reported a variety of ABC success, this study proposes the following hypotheses:

H1: The higher the degree of $\mathrm{ABC}$ implementation success, the higher the user's satisfaction with the ABC system.

H2: The higher the degree of $\mathrm{ABC}$ implementation success, the greater the extent of the $\mathrm{ABC}$ system usage.

H3: The higher the degree of $\mathrm{ABC}$ implementation success, the more the benefits gained from the ABC system.

\section{Methodology}

A structured questionnaire has been used in this study for data collection purposes. The questionnaire was sent to 226 manufacturing companies operating in Riyadh province, Saudi Arabia. The questionnaire starts with demographic information 
about the manufacturing company. After that, the respondent is asked whether his or her company implements activity-based costing. If the answer to this question is "yes", the respondent then is directed to answer sections A, B, and C. If the answer is "no", the respondent is directed to answer section D to figure out the reasons for not implementing ABC by his company.

Section A seeks the respondents' perception of the degree of ABC implementation success in their respective companies. The perceived success of $\mathrm{ABC}$ in this section is measured using a five-point Likert Scale where " $1=$ extremely unsuccessful; $2=$ unsuccessful; $3=$ average; $4=$ successful; and 5= extremely successful". The second question in Section A is asking the respondents to indicate their level of satisfaction with the ABC system in three areas as a methodology for calculating products and services costs, as a performance measurement system, and for the system capacity to direct cost reduction efforts. User satisfaction in these areas is measured using a four-point Likert Scale where " $1=$ dissatisfied; $2=$ needs improvements; $3=$ seems reasonable; and 4= very satisfied". Sections B and C collect data regarding the extent of ABC use and the benefits obtained from its implementation using a five-point Likert Scale where " $1=$ strongly disagree and 5= strongly agree". Out of the 226 questionnaires distributed, 75 responses were obtained from $\mathrm{ABC}$ implementers. 75 different sized companies confirmed that they are implementing $\mathrm{ABC}$ and have answered sections $\mathrm{A}, \mathrm{B}$, and $\mathrm{C}$ of the questionnaire.

The One-way between-groups Analysis of Variance (ANOVA) is used for data analysis. To test for hypotheses, variables components (three components for user satisfaction, six components for $\mathrm{ABC}$ extent of use, and fifteen components for the magnitude of benefits obtained from ABC implementation) have been aggregated for the ANOVA test. The respondents' companies were classified into three groups with regards to the degree of ABC implementation success namely; average success group, successful group, and very successful group. No answer was received from any ABC implementer company with a perceived unsuccessful level. The mean score of each aggregated variable for each degree of success group was obtained and F-value with its level of significance (P-value) was recorded to detect the variation between groups with regards to each aggregated variable. To find out where the significant difference exists (between each pair of groups), the Post Hoc analysis was used for the aggregated variables. Finally, the ANOVA test was run for each component under the main variables. The purpose of this test is to detect the significant variation among varying success groups for each component which comprise the overall variation of the main variables of user satisfaction, the extent of use, and the magnitude of benefits.

\section{Results and Discussion}

\subsection{Hypotheses Testing}

Results presented in Tables 1 and 2 demonstrate the findings of hypotheses testing. The level of ABC implementation success has been categorized based on the questionnaire responses into three categories namely; Average ( $n=16$ ), successful ( $n=38$ ), and very successful $(n=21)$ companies. In order to test for the relationship between the level of ABC implementation success and; user satisfaction, the extent of use, and magnitude of benefits, the Analysis of Variance - between groups (ANOVA) and the Post Hoc for Pair Group Analysis are used. Table 1 presents the mean score for each dependent variable, F-Value of variance (between groups), and the level of significance for each recorded variance. The significance of variance between the three levels of success' groups indicates that there is a significant association between the given dependent variable and the level of ABC implementation success. Table 2 locates the significant difference, that was detected by ANOVA analysis between groups, to each pair of groups of companies that were classified according to the level of ABC implementation success.

\subsubsection{The association between the level of ABC implementation success and user satisfaction}

User's satisfaction with $\mathrm{ABC}$ implementation variable consists of three components which are 1- satisfaction with $\mathrm{ABC}$ as a methodology for calculating product and service costs, 2- satisfaction with ABC as a performance measurement system, and 3- satisfaction with $\mathrm{ABC}$ for its ability to provide information to direct cost reduction efforts. Each component has been determined by respondents on a scale of 1 to 5 . The scores given by each respondent to these three components have been aggregated to represent the overall satisfaction of a given user (respondent) with the ABC system. Then, the respondents were categorized into three groups based on the level of ABC implementation success namely; average, successful, and very successful. The mean score of each group of respondents is obtained to reflect the user satisfaction level with the ABC system within each group. As presented in Table 1, the mean score of overall user satisfaction with the ABC system was (8.75) for the average level of success group, (9.16) for the successful group, and (11.24) for the very successful group. The variation in the level of user satisfaction between groups is significant at $(P<0.01)$ level. The results in Table 1 showed that the higher the success of $\mathrm{ABC}$ implementation, the higher the satisfaction of the system user. It is obvious that there is a significant association between the level of ABC implementation success and user satisfaction with the ABC system, hence, Hypothesis 1 is supported. Post Hoc Analysis provided in Table 2 compares the mean score of each pair group to locate the significant difference that was detected in Table 1. The findings of this analysis revealed that the user's satisfaction level of the group with very successful implementation is significantly higher than each of the other groups at $(P<0.01)$. The group of users who perceive their implementation of $A B C$ to be very successful is satisfied with $A B C$ outcomes more than those users who perceive their implementation of the $\mathrm{ABC}$ system to be only successful or average.

\subsubsection{The association between the level of ABC implementation success and extent of use}

The extent of $\mathrm{ABC}$ use variable consists of six components which are the use of $\mathrm{ABC}$ in; 1- product and service costing, 2cost management, 3- pricing decisions, 4- determining customer profitability, 5- outsourcing decisions, and 6- performance 
measurement. The same procedures performed with satisfaction variable is used here as well. Each component of $\mathrm{ABC}$ use is measured on a scale of 1 to 5 . The scores given by each respondent to each of the six components of $A B C$ use have been aggregated to reflect the overall extent of $\mathrm{ABC}$ use by a given user (company). The mean score of each group of respondents (with different levels of $\mathrm{ABC}$ implementation success) is obtained to represent the extent of $\mathrm{ABC}$ use by each group. The results presented in Table 1 showed that the mean score of the overall use of the ABC system was (22.5) for the average level of ABC success group, (24.53) for the successful group, and (25.95) for the very successful group. The variation in the extent of use between groups is significant at $(P<0.01)$ level. The results demonstrate that the extent of ABC use is positively associated with the level of $\mathrm{ABC}$ implementation success. ABC is used widely and extensively for more purposes by those organizations which achieve a higher level of success in ABC implementation. Consequently, the results support Hypothesis 2. Pair group comparison provided by the Post Hoc analysis in table 2 locates the significant difference that was detected by ANOVA between groups test. Companies with the very successful implementation of $\mathrm{ABC}$ reported a larger extent of $\mathrm{ABC}$ use when compared to companies with successful or average success implementation of ABC. Very successful ABC implementers use $\mathrm{ABC}$ in their organizational activities more than each of the other groups (average success and successful) with a significant difference at $(P<0.05)$.

Table 1

Analysis of variance - Aggregated Variables

\begin{tabular}{|c|c|c|c|c|c|}
\hline \multirow[b]{2}{*}{ Dependent Variables } & \multicolumn{3}{|c|}{ Mean Score } & \multicolumn{2}{|c|}{$\begin{array}{c}\text { ANOVA } \\
\text { (Between Groups) }\end{array}$} \\
\hline & $\begin{array}{l}\text { Average } \\
(n=16)\end{array}$ & $\begin{array}{l}\text { Successful } \\
(n=38)\end{array}$ & $\begin{array}{c}\text { Very Successful } \\
(n=21)\end{array}$ & $F$-value & $p$-value \\
\hline User Satisfaction with $\mathrm{ABC}$ Implementation & 8.75 & 9.16 & 11.24 & $14.250^{* * *}$ & .000 \\
\hline Extent of Use & 22.50 & 24.53 & 25.95 & $5.616^{* * *}$ & .006 \\
\hline Magnitude of Benefits from ABC Implementation & 58.25 & 62.87 & 66.62 & $6.922 * * *$ & .002 \\
\hline
\end{tabular}

***. The mean difference is significant at the 0.01 level.

\subsubsection{The association between the level of ABC implementation success and the magnitude of benefits.}

$\mathrm{ABC}$ system adopters have reported a wide range of benefits that, according to them, outweigh its cost. This study selects 15 major benefits of the ABC system that were summarized from previous research. These benefits are related to cost determination, cost reduction, improving profitability analysis, and other benefits which are presented in Table 3 and will be discussed in the next section. The selected (15) benefits are measured on a scale of 1 to 5 . The scores given by each respondent to each of the 15 benefits have been aggregated to comprise the magnitude of ABC benefits reported by each respondent company. Consequently, the mean score of each group of respondents is obtained to represent the magnitude of ABC benefits reported by each group. The results demonstrated in Table 1 show that the mean score of the overall benefits reported by companies was (58.25) for companies with an average level of ABC success, (62.87) for companies which perceive their implementation of $\mathrm{ABC}$ to be successful, and (66.62) for companies which assert that they are very successful with ABC implementation. The results revealed a significant difference in the magnitude of $\mathrm{ABC}$ benefits reported by the three groups at $(P<0.01)$ level. Companies that have asserted a higher level of $\mathrm{ABC}$ implementation have reported more benefits gained from $\mathrm{ABC}$ implementation and vice versa. It is evident that the magnitude of $\mathrm{ABC}$ benefits gained by companies is positively and significantly associated with the achieved level of ABC implementation success. Accordingly, Hypothesis 3 is supported.

Table 2

Post Hoc Tests (Multiple Comparisons) - Aggregated Variables

\begin{tabular}{|c|c|c|c|c|c|}
\hline Dependent Variable & $\begin{array}{l}\text { (I) ABC Implementa- } \\
\text { tion Success }\end{array}$ & $\begin{array}{l}\text { (J) ABC Implementation } \\
\text { Success }\end{array}$ & Mean Difference $(I-J)$ & Std. Error & Sig. \\
\hline \multirow[t]{3}{*}{ User Satisfaction with $\mathrm{ABC}$ Implementation } & \multirow[t]{2}{*}{ Average } & Successful & -.40789 & .78442 & .862 \\
\hline & & Very Successful & $-2.48810 * * *$ & .81410 & .009 \\
\hline & & Very Successful & $-2.08020 * * *$ & .40576 & .000 \\
\hline \multirow[t]{3}{*}{ Extent of Use } & \multirow{2}{*}{ Average } & Successful & -2.02632 & 1.12624 & .179 \\
\hline & & Very Successful & $-3.45238 * *$ & 1.16885 & .012 \\
\hline & Successful & Very Successful & $-1.42607 * *$ & .58257 & .045 \\
\hline \multirow{3}{*}{$\begin{array}{l}\text { Magnitude of Benefits from ABC Imple- } \\
\text { mentation }\end{array}$} & Average & Successful & -4.61842 & 2.53921 & .172 \\
\hline & & Very Successful & $-8.36905 * * *$ & 2.63527 & .007 \\
\hline & Successful & Very Successful & $-3.75063 * *$ & 1.31347 & .016 \\
\hline
\end{tabular}

The significance levels are indicated as *significant at the 0.10 level; **significant at the 0.05 level; and ***significant at the 0.01 level.

\section{4-2 Additional Detailed Analysis}

Table 3 provides further analysis for each component under the three main variables (satisfaction, use, and benefits). ANOVA analysis demonstrated in Table 3 provides a comparison of the mean score of each respondents' group (average ABC success implementers, successful implementers, and very successful implementers) and the variation between groups with its level of significance with regards to each component (sub-variable).

\subsubsection{User's satisfaction}

As displayed in Table 3, companies with the average success of ABC implementation showed dissatisfaction with the ABC system as a methodology for calculating products and services costs with a mean score of (2.5). This is in conformity with 
the first hypothesis since they face difficulties in implementing the system which could be a result of their inability to; define the companies' activities for the system application, identifies the proper cost drivers, and allocate each activity cost into products and services. The lower level of success in the implementation of the ABC system has been reflected in their dissatisfaction with the system as a tool for calculating products and services costs. Companies that declared a successful level of $\mathrm{ABC}$ implementation showed a moderate level of satisfaction with $\mathrm{ABC}$ as a tool for calculating products and services costs whereas companies who believe that they are very successful in $\mathrm{ABC}$ implementation expressed satisfaction with $\mathrm{ABC}$ for calculating products and services costs. Satisfaction with $\mathrm{ABC}$ for this function is significantly different between groups at $(P<0.01)$ level. Companies with average success and a successful level of ABC implementation displayed moderate satisfaction with the ABC system as a performance measurement system with a mean score of (3) and (3.11) respectively. They displayed also moderate satisfaction with $\mathrm{ABC}$ when it is used for directing cost reduction efforts with a mean score of (3.25) and (3.05) respectively. In contrast, companies who declared a very successful level of ABC implementation showed a higher level of satisfaction with $\mathrm{ABC}$ system as a performance measurement system (3.62) and for its ability to provide information to direct cost reduction efforts (3.86) with significant differences at $(P<0.05)$ and $(P<0.01)$ respectively.

\subsubsection{Extent of use}

The results presented in Table 3 for items 4-9 revealed a significant variation in the extent of ABC use for four organizational activities that are; product and services costing, cost management, pricing decisions, and determining customer profitability. The three groups of companies showed extensive use of the ABC system for products/services costing and performance measurement. Despite the extensive use of the $\mathrm{ABC}$ system by the three groups of companies for products and services costing, a significant difference between groups is detected at $(P<0.05)$ level.

Table 3

Analysis of variance - Single Item

\begin{tabular}{|c|c|c|c|c|c|c|}
\hline & \multirow[b]{2}{*}{ Dependent Variables } & \multicolumn{3}{|c|}{ Mean Score } & \multicolumn{2}{|c|}{$\begin{array}{c}\text { ANOVA } \\
\text { (Between Groups) }\end{array}$} \\
\hline & & $\begin{array}{l}\text { Average } \\
(n=16)\end{array}$ & $\begin{array}{c}\text { Successful } \\
(n=38)\end{array}$ & $\begin{array}{c}\text { Very Success- } \\
\text { ful } \\
(n=21)\end{array}$ & $F$-value & $p$-value \\
\hline & \multicolumn{6}{|l|}{ User Satisfaction with ABC system: } \\
\hline 1 & A methodology for calculating product and service costs & 2.5 & 3 & 3.76 & $13.257 * * *$ & .000 \\
\hline 2 & A performance measurement system & 3 & 3.11 & 3.62 & $4.747 * *$ & .012 \\
\hline \multirow[t]{2}{*}{3} & For its ability to provide information to direct cost reduction efforts & 3.25 & 3.05 & 3.86 & $9.682 * * *$ & .000 \\
\hline & $A B C$ is Used for: & & & & & \\
\hline 4 & Product and service costing & 4 & 4.13 & 4.43 & $3.667 * *$ & .031 \\
\hline 5 & Cost management & 3.5 & 4.11 & 4.57 & $7.860 * * *$ & .001 \\
\hline 6 & Pricing decisions & 3.75 & 4.16 & 4.76 & $10.881 * * *$ & .000 \\
\hline 7 & Determine customer profitability & 3.5 & 4.05 & 4.38 & $3.380 * *$ & .041 \\
\hline 8 & Outsourcing decisions & 3.75 & 4.03 & 3.62 & 1.702 & .191 \\
\hline \multirow[t]{2}{*}{9} & Performance measurement & 4 & 4.05 & 4.19 & .586 & .560 \\
\hline & Benefits gained form ABC implementation: & & & & & \\
\hline 10 & Better overhead cost allocation & 3.75 & 4.29 & 4.62 & $5.283 * * *$ & .008 \\
\hline 11 & More accurate product or service costs & 4 & 4.21 & 4.62 & $4.253 * *$ & .019 \\
\hline 12 & Assisting in cost reduction efforts & 3.75 & 4.13 & 4.62 & $5.945 * * *$ & .004 \\
\hline 13 & Cost control improvement & 4.25 & 4.29 & 4.57 & 1.748 & .183 \\
\hline 14 & Better performance measurement & 4 & 4.03 & 4.33 & 2.053 & .137 \\
\hline 15 & Identifying and elimination of non-value added activities & 4 & 4.03 & 4.38 & 1.581 & .214 \\
\hline 16 & Provision of more accurate and timely information for decision making & 4 & 4.26 & 4.52 & 1.366 & .263 \\
\hline 17 & Better budgeting & 3.75 & 4.13 & 4.48 & $3.776 * * *$ & .029 \\
\hline 18 & Provision of incentives to improve service excellence & 3.75 & 4.08 & 4.29 & 1.494 & .233 \\
\hline 19 & Increase the productivity of the employees in the company & 4.25 & 3.89 & 4.24 & 2.064 & .136 \\
\hline 20 & Better pricing policy & 3.75 & 4.26 & 4.43 & 2.058 & .137 \\
\hline 21 & Increase in the company competitive capability & 3.75 & 4.21 & 4.48 & $2.836^{*}$ & .067 \\
\hline 22 & Improved Analysis of customer profitability & 3.75 & 4.24 & 4.24 & .907 & .409 \\
\hline 23 & Improved Analysis of products and services profitability & 3.75 & 4.5 & 4.38 & $3.606 * *$ & .033 \\
\hline 24 & Improved Analysis of regional profitability & 3.75 & 4.32 & 4.43 & 1.652 & .200 \\
\hline
\end{tabular}

Companies with a very successful level of ABC implementation uses the system in products and services costing (mean; 4.43) more than the other two groups; successful companies (4.13) and average success companies (4). Furthermore, the three groups of companies reported above-average to extensive use of the $\mathrm{ABC}$ system for cost management, pricing decision, and customer profitability determination. However, significant differences are still detected between the three groups of companies in the extent of $\mathrm{ABC}$ use for cost management at $(P<0.01)$, pricing decisions at $(P<0.01)$, and customer profitability determination at $(P<0.05)$ levels. However, there is no significant difference between the three groups of companies in using the ABC system for performance measurement with mean scores of (4) for average success companies, (4.05) for successful companies, and (4.19) for very successful companies. 


\subsubsection{Benefits of ABC system}

Companies that have chosen to adopt $\mathrm{ABC}$ and continued with the implementation of the system have reported a wide range of benefits. In this study, the three groups of companies which declared different levels of ABC implementation success, have reported above-average of $\mathrm{ABC}$ benefits for the 15 areas that were included in the questionnaire with obvious incremental differences that are associated with the levels of $\mathrm{ABC}$ implementation success. As presented in Table 3, the three groups of companies showed a significant variation regarding certain benefits gained from ABC implementation. Higher successful implementers of the system reported more benefits in the areas of better overhead allocation, assisting in cost reduction efforts, and better budgeting with significant differences at $\mathrm{P}<0.01$ compared to lower successful implementers. In addition, significant differences at $\mathrm{P}<0.05$ were detected for reported benefits in the areas of accurate products/services costs and improved analysis of products/services profitability.

\section{Conclusion}

ABC system assists management in identifying the company's activities and the consumption of resources by each activity. Such an understanding of the links between resources, activities, and products facilitates products' cost management by managing the costs of activities. ABC assists management in identifying the non-value added activities. Thus, management can eliminate those activities to reduce products' costs. However, ABC users declared varying levels of satisfaction with $\mathrm{ABC}$ and reported different uses of the system. More importantly, not all users of $A B C$ receive the same number of outcomes as shown by this study results. Users indicated divers types and a varying amount of benefits that were gained from ABC implementation. The findings of this study provide an understanding of those variations and answer the question of why companies receive varying outcomes from $\mathrm{ABC}$ implementation. As stipulated in the results section, companies have achieved varying degrees of success in their efforts for $\mathrm{ABC}$ implementation. The varying degree of success could be attributed to the expertise within each company and the ability of its personnel to align the ABC system with other financial, operational, and administrative systems. The proper identification of activities and selection of appropriate cost drivers facilitate the successful implementation of the $\mathrm{ABC}$ system. However, previous studies pointed out several technical and behavioral factors that are essential for $\mathrm{ABC}$ Success. According to the findings of this study, the degree of ABC implementation success will be reflected in the extent of $\mathrm{ABC}$ use within a company, the type and amount of benefits gained, and consequently the user's satisfaction with the system. As mentioned earlier in this study, three degrees of success have been identified by ABC implementers. Manufacturing companies in Saudi Arabia that have been surveyed by this study perceive their implementation of $A B C$ to be either moderately successful (average success), successful, or very successful. The results of this study showed that the degree of success is associated positively with the extent of use, benefits gained, and user satisfaction with $\mathrm{ABC}$.

When the company succeeds in the technical implementation of $\mathrm{ABC}$ and considers the behavioral aspects for the system success, the company utilizes the system extensively and depends on the information provided by the system for products and services costing, cost management, pricing decisions, profitability analysis, and performance measurement. Successful implementation of $\mathrm{ABC}$ and extensive use of the system yield a wide range of benefits and maximize those benefits to the possible extent. The more benefits that are the result of efficient and successful implementation of ABC optimize the positive effect of $\mathrm{ABC}$ on organizational performance which is reflected in the user's satisfaction with the system.

\section{References}

Agbejule, A. (2006). Motivation for activity-based costing implementation Administrative and institutional influences. Journal of Accounting \& Organizational Change, 2(1), $42-73$.

Albalaki, F. M. M., Abdullah, Z., \& Kamardin, H. (2019). The Influence of External Contingency Factors and Activity-Based Costing Implementation on Organizational Performance. Jurnal Pengurusan (UKM Journal of Management), 55.

Argyris, C., \& Kaplan, R. S. (1994). Implementing new knowledge: The case of activity-based costing. Accounting Horizons , 8(3), 83 .

Brown, R. E., Myring, M. J., \& Gard, C. G. (1999). Activity-Based Costing in Government: Possibilities and Pitfalls. Public Budgeting \& Finance, 19(2), 3-21.

Cagwin, D., \& Bouwman, M. J. (2002). The association between activity-based costing and improvement in financial performance. Management Accounting Research, 13(1), 1-39.

Chenhall, R. H. (2004). The role of cognitive and affective conflict in early implementation of Activity-Based Cost Management. Behavioral Research in Accounting , 16, 19.

Chong, V. K., \& Cable, R. (2002). A study on the implementation of an activity-based costing (ABC) system in an Australian Oil and Gas Company. Asian Reliew of Accounting, 10 (2).

Cohen, S., Venieris, G., \& Kaimenaki, E. (2005). ABC: adopters, supporters, deniers and unawares. Managerial Auditing Journal, 20(9), 981-1000.

Cooper, R., \& Kaplan, R. S. (1988). Measure Costs Right: Make the Right Decisians. HARVARD BUSINESS REVIEW .

Cooper, R., \& Kaplan, R. S. (1992). Activity-Based Systems: Measuring the costs of resource usage. Accounting Horizons, $6(3), 1$.

Covaleski, M. A., Dirsmith, M. W., \& Samuel, S. (1996). Managerial accounting research: the contributions of organizational and sociological theories. Journal of Management Accounting Research, 8, 1-36. 
Duh, R.-R., Lin, T. W., Wang, W.-Y., \& Huang, C.-H. (2009). The design and implementation of Activity-Based Costing. International Journal of Accounting , 17(1), 27-52.

Faria, A. R., Ferreira, L., \& Trigueiros, D. (2018). Analyzing customer profitability in hotels using activity based costing. Tourism \& Management Studies, 14(3), 65-74.

Foster, G., \& Swenson, D. W. (1997). Measuring the success of activity-based cost management and its determinants. Journal qf Management Accounting Research, 9.

Gosselin, M. (1997). The effect of strategy and organizational structure on the adoption and implementation of Activity-Based Costing. Accounting, Organizations and Society, 22(2), 105-122.

Hilton, R. W. (2008). Managerial accounting Creating Vallue in a Dynamic Business Environment (Seventh Edition). New York: McGraw-Hill.

Innes, J., \& Mitchell, F. (1995). A survey of Activity-Based Costing in the U.K.'s largest companies. Management Accounting Research , 6, 137-153.

Innes, J., Mitchell, F., \& Sinclair, D. (2000). Activity-based costing in the U.K.'s largest companies: a comparison of 1994 and 1999 survey results. Management Accounting Research, 11, 349-362.

Jarrar, N. S., Smith, M., \& Dolley, C. (2007). Perceptions of preparers and users to accounting change: a case study in an Australian university. Managerial Auditing Journal, 22(1), 80-94.

Kennedy, T., \& Affleck-Graves, J. (2001). The impact of activity-based costing techniques on firm performance. Journal of Management Accounting Research, 13(1), 19-45.

Kennett, D. L., Durler, M. G., \& Downs, A. (2007). Activity-based costing in large U.S. cities: Costs and benefits. The Journal of Government Financial Management, 56(1), 20.

Krumwiede, K. R. (1998). The implementation stages of activity-based costing and the impact of contextual and organizational factors. Journal of Management Accounting Research, 10, 239.

Liu, L. Y., \& Pan, F. (2007). The implementation of Activity-Based Costing in China: An innovation action research approach. The British Accounting Review, 39(3), 249-264.

Maelah, R., \& Ibrahim, D. N. (2006). Activity Based Costing (ABC) adoption among manufacturing organizations: The case of Malaysia. International Journal of Business and Society, 7(1), 70.

Maiga, A. S., \& Jacobs, F. A. (2008). Extent of ABC use and its consequences. Contemporary Accounting Research, 25(2), 533-660.

Major, M., \& Hopper, T. (2005). Managers divided: Implementing ABC in a Portuguese telecommunications company. Management Accounting Research , 16, 205-229.

McGowan, A. S., \& Klammer, T. P. (1997). Satisfaction with activity-based cost management implementation. Journal of Management Accounting Research, 9, 217.

Narayanan, V. G., \& Sarkar, R. G. (2002). The impact of activity-based costing on Managerial Decisions at Insteel Industries-A Field Study. Journal of Economics \& Management Strategy, 11 (2), 257-288.

Nolan, P. M. (2004). Critical success factors for implementing an enterprise-wide ABC solution. Journal of Performance Management, 17(3), 15.

Otley, D. (2008). Did Kaplan and Johnson get it right? Accounting, Auditing \& Accountability Journal, 21 (2), $229-239$.

Pietrzak, Ž., Wnuk-Pel, T., \& Christauskas, Č. (2020). Problems with activity-based costing implementation in Polish and Lithuanian companies. Inžinerine ekonomika-Engineering Economics, 31(1) 26-38.

Quinn, M., Elafi, O., \& Mulgrew, M. (2017). Reasons for not changing to activity-based costing: a survey of Irish firms. PSU Research Review, 1(1) 63-70.

Shields, M. D. (1995). An empirical analysis of firms' implementation experiences with Activity-Based Costing. Journal of Management Accounting Research, 7.

Sorros, J., Karagiorgos, A., \& Mpelesis, N. (2017). Adoption of activity-based costing: A survey of the education sector of Greece. International Advances in Economic Research, 23(3), 309-320.

Souissi, M. (2002). Activity-Based Costing approach: How it has been perceived in Japan. International Journal of Management , 19 (2), 343.

Stončiuvienė, N., Ūsaite-Duonielienė, R., \& Zinkevičienè, D. (2020). Integration of activity-based costing modifications and LEAN accounting into full cost calculation. Engineering Economics, 31(1), 50-60.

Stratton, W. O., Desroches, D., Lawson, R. A., \& Hatch, T. (2009). Activity-based costing: Is it still relevant? Management Accounting Quarterly, 10(3), 31.

Swenson, D. (1995). The benefits of Ctivity-Based Cost Management to the manufacturing industry. Journal of Management Accounting Research, 7.

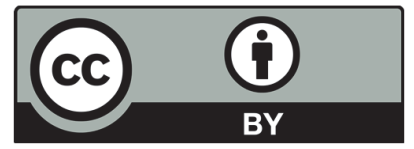

(C) 2020 by the authors; licensee Growing Science, Canada. This is an open access article distributed under the terms and conditions of the Creative Commons Attribution (CC-BY) license (http://creativecommons.org/licenses/by/4.0/). 